\title{
Experimentações narrativas em Twin Peaks: The Return: narração paramétrica na ficção televisiva contemporânea ${ }^{1}$
}

\section{Narrative Experiments in Twin Peaks: The Return: parametric narration in contemporary television fiction}

Henrique Bolzan Quaioti² e Rogério Ferraraz ${ }^{3}$ 


\section{Resumo}

O objetivo deste artigo é identificar a existência de narração paramétrica conceito originalmente aplicado por David Bordwell a certas obras fílmicas - na ficção televisiva contemporânea, bem como apontar uma hipótese sobre o propósito do uso desse modo narrativo. Para tanto, elegemos como corpus a série Twin Peaks: the return (2017), dirigida por David Lynch e escrita por ele e por Mark Frost. Acreditamos ser possível identificar que existe pelo menos um evento narrativo na série que pode ser considerado paramétrico, que denominamos "Dale Cooper letárgico". Através da análise desse evento, pretendemos demonstrar, que, usando uma narrativa paramétrica, Lynch e Frost subvertem grande parte das convenções que a própria série original engendrou em 1990, trazendo, assim, novas experimentações à ficção televisiva.

Palavras-Chave

Análise da ficção televisiva, narração paramétrica, Twin Peaks: the return.

\section{Abstract}

This paper aims to identify the existence of parametric narration a concept originally applied by David Bordwell to certain film works in contemporary television fiction and to hypothesize the purpose of using this narrative mode. To this end, we chose the TV series Twin Peaks: The Return (2017), directed by David Lynch and written by himself and Mark Frost. We believe we can identify at least one narrative event in the series that can be considered parametric, that we call "lethargic Dale Cooper". Analyzing this narrative event, we intend to demonstrate that Lynch and Frost subvert most of the conventions that the original series itself engendered in 1990 by using a parametric narrative, thus bringing new experiments to television fiction.

\section{Keywords}

Analysis of television fiction, parametric narration, Twin Peaks: The Return. 


\section{Introdução}

O objetivo deste artigo é identificar a existência de narração paramétrica na ficção televisiva, bem como apontar uma hipótese sobre o propósito do uso desse modo narrativo. Para tanto, elegemos como corpus de análise Twin Peaks: The Return (2017), série dirigida por David Lynch e escrita por ele e Mark Frost. De acordo com David Bordwell (1985), que elaborou esse conceito para descrever, originalmente, certos tipos de narrativas cinematográficas, o modo narrativo paramétrico "aplica-se a cineastas isolados e filmes esparsos" (p. 274, tradução nossa4). Por esse motivo, acreditamos ser possível encontrar esse tipo de narrativa na série em questão ${ }^{5}$, mesmo que Bordwell nunca o tenha identificado em outras obras de Lynch e Frost, fílmicas ou televisivas.

É importante ressaltar que isso não é o mesmo que dizer que Twin Peaks: The Return seja uma série estruturada como narrativa paramétrica em sua integralidade. O que o artigo se propõe a fazer é identificar esse modo narrativo em apenas uma parcela da série, isto é: existe pelo menos um eixo narrativo na série que pode ser considerado paramétrico, comprovando, assim, um caso de narrativa paramétrica na televisão. O artigo não perde de vista que, em outras partes, a série opera segundo outros modos narrativos, porém, identificar todos eles não é o objetivo deste trabalho.

Tem-se em mente, conforme apontam Simone Maria Rocha e Renato Luiz Pucci Júnior, que, ao escolher uma determinada perspectiva metodológica analítica, o "pesquisador da televisão não precisa partir do marco zero [...], pois muito do que é praticado pelos pesquisadores de cinema pode ser transposto para o estudo dos programas televisivos ou, pelo menos, experimentado com larga chance de sucesso" (ROCHA; PUCCI JR, 2016, p. 9). Sendo assim, este artigo 
foi pensado a partir das análises fílmicas neoformalistas ${ }^{6}$ de Bordwell (1985) e Kristin Thompson (1988) e reelaborado para as diferenças que estão presentes em uma análise de outro meio, a televisão.

Como Rocha e Pucci Jr. (2016) observam, "entre análise fílmica e análise televisual há diferenças não desprezíveis", principalmente em relação à "longa duração dos produtos seriados" (p. 10). Isso não é diferente com o objeto deste artigo, Twin Peaks: The Return, que possui, no total, aproximadamente 18 horas de material em vídeo, tamanho gigantesco se comparado a um longa-metragem. Rocha e Pucci Jr. levantam esta questão:

Ao menos desde meados da primeira década deste século, têm sido realizadas tentativas mais bem sucedidas, no sentido de estabelecer os fundamentos da metodologia analítica de produtos televisivos. O nome de maior destaque é Jeremy Butler. Em Television style (2010), além de fazer o levantamento dos embates de pesquisadores e críticos diante dessa problemática, ele efetua análises que têm servido e ainda servirão de modelo. No entanto, Butler não responde à questão central, acima levantada: qual o peso heurístico, isto é, capaz de proporcionar conhecimento, da análise de cenas pertencentes a um produto de dimensões colossais? (ROCHA; PUCCI JR, 2016, p. 11)

Ter esse problema a ser debatido não reduz a efetividade e os méritos metodológicos deste artigo, pelo contrário. De fato, é tarefa árdua, para não dizer impossível e inócua, realizar a análise de todos os episódios de Twin Peaks: The Return - nem mesmo a análise fílmica de um longa-metragem se presta a isso -, porém acreditamos que a análise de um "evento narrativo" possa contribuir para desvendar aspectos narrativos do produto como um todo.

Simone Rocha denomina o que seria um evento narrativo:

No caso das narrativas ficcionais, uma das dificuldades em se trabalhar com tais produtos diz respeito ao volume significativo do material em questão. neoformalista é uma abordagem possível dentre tantas outras. Para Thompson (1988), tal abordagem "é pensada para ser a mais apropriada para filmes altamente estilizados ou não usuais" (p. 5, tradução nossa). No original: "a formalist method is thought to be most apporpriate to highly stylized or unusual films". 
Nesse sentido, as unidades de análise nem sempre são precisas e muitas vezes o que os autores adotam são trechos (como cenas, sequências, capítulos ou episódios) de uma narrativa. Ainda que difícil, temos a convicção de que a visão do conjunto é que seria a mais produtiva para a questão que apontamos neste texto e, portanto, optamos por adotar o que chamamos de "eventos narrativos" como forma de adentrar no material. Esses eventos compõem uma trama (ou uma sub-trama) e poderiam ser traduzidos pelos acontecimentos, pelas ações que garantem o desenvolvimento da história [...]. Um evento pode ou não durar vários capítulos e, em função das características do consumo de narrativas seriadas televisivas, necessitar do recurso da redundância (THOMPSON, 2003). Acompanhá-lo permite ao analista visualizar o entrelaçamento das tramas, o uso de indicadores temporais claros, e a inserção de causas pendentes para a devida articulação de sequencias separadas temporalmente. (ROCHA; PUCCI JR., 2016, p. 185-186)

Para este artigo, selecionamos o que denominamos evento narrativo "Dale Cooper Letárgico". No entanto, antes de esmiuçá-lo, é necessário contextualizar a série televisiva que deu origem ao produto que é objeto de análise deste artigo: Twin Peaks (1990-1991). Esta série televisiva, elaborada por Mark Frost e David Lynch, foi transmitida pela rede televisiva americana ABC. Twin Peaks contou com duas temporadas, estreando em 8 de abril de 1990 e encerrando em 10 de junho de 1991, totalizando 30 episódios A história principal envolve a investigação do misterioso assassinato de Laura Palmer (Sheryl Lee), colegial popular que morava na pequena cidade de Twin Peaks. Esta investigação fica a cargo do agente especial do FBI Dale Cooper (Kyle MacLachlan), juntamente com o trabalho da polícia local. Conforme o investigador tenta desvendar o mistério do assassinato, o espectador toma conhecimento, juntamente com o personagem, de realidades insólitas de cada habitante de Twin Peaks, e os acontecimentos vão se tornando gradativamente mais macabros e inexplicáveis. Com isso, o programa foi considerado um marco (FERRARAZ, 2007) e contribuiu para que a transformação do modo de fazer séries para a televisão, conforme apontam autores como 
Jason Mittell (2012, 2015), Kristin Thompson (2003), Jean-Pierre Esquenazi (2011) e Cássio Starling Carlos (2006).

O último episódio da segunda temporada - vigésimo segundo da segunda temporada e trigésimo no total -, vimos o protagonista da série, o agente do FBI Dale Cooper, adentrar o Black Lodge, outra dimensão, representada por séries intermináveis de salas e corredores com cortinas vermelhas e habitado por personagens estranhos ${ }^{8}$. Um destes personagens dirige-se ao agente e 0 alerta sobre o surgimento do seu doppelgänger. Irrompe, então, o "Evil Cooper", o duplo maligno de Dale Cooper. Enquanto o agente Cooper (também referido como Good Cooper) fica preso no Black Lodge, o "Evil Cooper" liberta-se. Na última cena desse episódio, vemos o doppelgänger do mal, que os demais policiais pensam tratar-se do agente Cooper, chocar sua cabeça contra o espelho do banheiro e, através da imagem refletida, surgir a figura do espírito maligno e assassino BOB (Frank Silva). Somente os personagens daquela outra dimensão e os espectadores da série têm essa informação.

A partir de uma frase dita por Laura Palmer ao agente Dale Cooper quando ambos se encontram no Black Lodge, no último episódio da segunda temporada da série, em 1991, "eu o verei novamente em 25 anos", por muito tempo especulou-se uma volta de Twin Peaks, o que finalmente ocorreu, em $2017^{9}$, quando Lynch e Frost se reuniram novamente e realizaram o projeto Twin Peaks: The Return ${ }^{10}$, uma espécie de minissérie em 18 episódios. 0 programa foi produzido e exibido pelo canal por assinatura Showtime nos Estados Unidos e teve distribuição internacional via Netflix. observar que Ferraraz e Magno (2019) empreenderam uma análise da presença do inquietante em Twin Peaks: The Return. 
A principal linha narrativa da terceira temporada, ambientada em 2016, conta as ações macabras praticadas pelo "Evil Cooper" e, paralelamente, "Good Cooper" conseguindo escapar do Black Lodge. Ao voltar para a nossa dimensão, o corpo do agente Cooper aparece no lugar do corpo de Dougie Jones, homem com as mesmas características físicas de Cooper e interpretado pelo mesmo ator. Dougie é casado com Janey-E (Naomi Watts), com quem teve um filho chamado Sonny Jim, e trabalha como agente de seguros. No momento em que o espectador é apresentado a Jones, ele está com uma prostituta. Depois de terminar o encontro, ela vai tomar banho e, no quarto, sozinho, o braço esquerdo de Dougie fica dormente. Ele passa mal, cai e vomita no chão. Inesperadamente, ele é haurido para trás e seu corpo se desmaterializa para ser substituído pelo corpo do agente Cooper, que se transporta através de uma tomada, retornando à dimensão terrestre após 25 anos aprisionado. Estranhamente, o bom Cooper volta em um estado mental letárgico, não conseguindo falar ou agir corretamente; é exatamente este evento narrativo que será o objeto de análise deste artigo.

O acontecimento descrito ocorre no episódio 3 de Twin Peaks: The Return. Depois de vários acontecimentos inusitados, Cooper, no episódio 4, chega até a casa de Dougie e é recebido por Janey-E, que acredita tratar-se de seu marido. The Return tem 18 episódios, e o personagem do agente federal não aparece em apenas dois deles; dos 16 em que ele participa, 11 são quando Cooper está letárgico, despertando para seu estado normal apenas no $16^{\circ}$ episódio. Desse modo, o corpus deste estudo pode ser delimitado do episódio 3 ao 15, contendo, aproximadamente, pouco mais de 2 horas de material em vídeo. A Tabela 1 esquematiza o evento narrativo em lógica temporal:

Evento narrativo do Dale Cooper letárgico

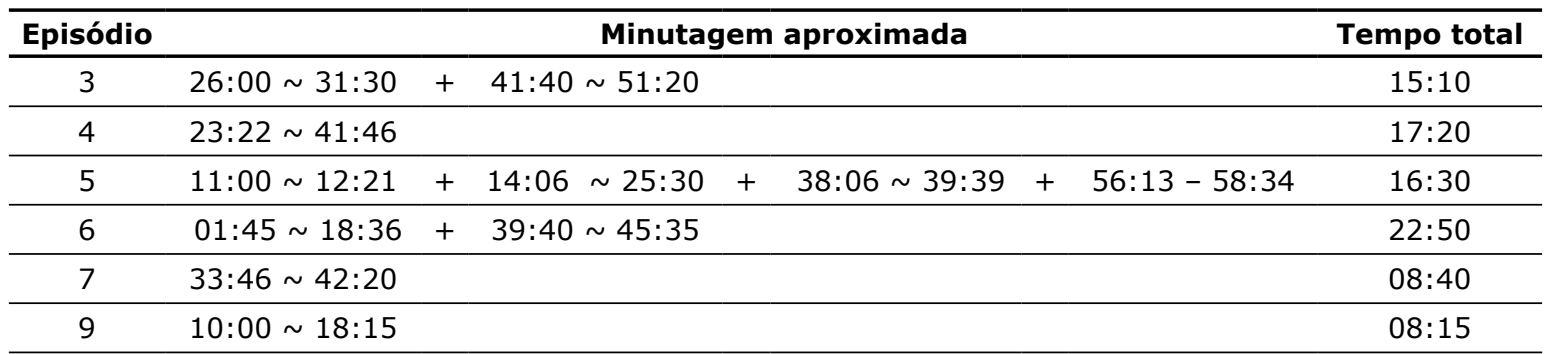


Evento narrativo do Dale Cooper letárgico

\begin{tabular}{cccc}
\hline Episódio & & Minutagem aproximada & Tempo total \\
\hline 10 & $09: 35 \sim 12: 00+15: 20 \sim 18: 20+20: 50 \sim 21: 25$ & $06: 00$ \\
\hline 11 & $34: 00 \sim 37: 40+39: 40 \sim 57: 00$ & $22: 30$ \\
\hline 12 & $13: 20 \sim 13: 50$ & & $00: 30$ \\
\hline 13 & $02: 00 \sim 07: 00+28: 20 \sim 34: 20+36: 00 \sim 39: 00$ & $14: 00$ \\
\hline 15 & $38: 00 \sim 42: 00$ & & $04: 00$ \\
\hline Tempo total do evento narrativo: & min aprox. & 126 \\
\hline
\end{tabular}

Tabela 1: Minutagem do evento narrativo "Dale Cooper letárgico"

Fonte: elaboração dos autores.

A tabela nos mostra todos os momentos em que o evento narrativo "Dale Cooper letárgico" marca presença nos episódios, com a minutagem do tempo em que ele se inicia e termina e, adiante, o tempo total de tela do evento narrativo em cada episódio.

Agora que delineamos o corpus deste trabalho, podemos voltar para a questão metodológica da análise. Um conceito fundamental neste artigo é o de "modo narrativo", que Bordwell (1985) define como "o processo pelo qual o syuzhet e o estilo do filme interagem no processo de informar e canalizar a construção da fabula pelo espectador" (p. 53, tradução nossa ${ }^{11}$ ). Para entendermos melhor, devemos, primeiramente, conceitualizar o significado de syuzhet, estilo e fabula ${ }^{12}$. Bordwell (1985) toma emprestado dos formalistas russos ${ }^{13}$ o termo syuzhet que, sinteticamente, quer dizer o conjunto estruturado de todos os eventos causais apresentados no filme como "ações, cenas, pontos de virada e reviravoltas" (BORDWELL, 1985, p. 50, tradução nossa ${ }^{14}$ ), tudo apresentado na ordem em

11 No original: "the process whereby the film's syuzhet and style interact in the course of cueing and channeling the spectator's construction of the fabula". mas sim ao termo utilizado por Bordwell, emprestado dos formalistas russos. russa, na década de 1920, mais especificamente para trabalhos em literatura. 
que o espectador assiste. A fabula é a construção mental da narrativa a partir do syuzhet, tentando sempre preencher elipses e estabelecer uma cronologia linear, mesmo que os eventos não sigam tal ordem no syuzhet. Para estilo, ele conceitua:

No sentido mais estrito, considero o estilo um uso sistemático e significativo de técnicas da mídia cinema em um filme. Essas técnicas são classificadas em domínios amplos: mise-en-scène (encenação, iluminação, representação e ambientação), enquadramento, foco, controle de valores cromáticos e outros aspectos da cinematografia, da edição e do som. (BORDWELL, 2013, p. 17)

Bordwell ainda diz que, em produtos narrativos (como é o caso do nosso objeto Twin Peaks: The Return), "esses dois sistemas coexistem" e o "syuzhet incorpora o filme como um processo 'dramatúrgico'", enquanto o "estilo incorpora em um aspecto técnico" (BORDWELL, 1985, p. 50, tradução nossa ${ }^{15}$ ). Na chamada narrativa clássica, por exemplo, o estilo deve ser invisível ${ }^{16}$, existente apenas para reforçar o syuzhet e conformar-se às convenções do cinema clássico.

Já na narração paramétrica, o "estilo é organizado no filme de acordo com princípios distintos da syuzhet, assim como um poema narrativo exibe padrões prosódicos ou uma cena operística cumpre uma lógica musical" (BORDWELL, 1985, p. 281, tradução nossa ${ }^{17}$ ). Kristin Thompson (1988), que contribuiu com diversas análises de filmes paramétricos, diz que "podemos caracterizar como paramétricos os filmes que permitem ao jogo de dispositivos estilísticos um grau significativo de independência do funcionamento e da motivação narrativa" (p. 247, tradução nossa ${ }^{18}$ ), ou seja, na narração paramétrica, diferentemente

No original: "in a narrative film these two systems coexist [...]. The syuzhet embodies the film as a 'dramaturgical' process; style embodies it as a 'technical' one".

Ideia próxima ao conceito de "transparência" aplicado à decupagem clássica, conforme descrito por Ismail Xavier (2005).

No original: "In parametric narration, style is organized across the film according to distinct principles, just as a narrative poem exhibits prosodic patterning or an operatic scene fulfills a musical logic".

No original: "we may characterize as parametric those films that allow the play of stylistic devices a significant degree of independence from narrative functioning and motivation". 
da narrativa clássica, os aspectos estilísticos formam um sistema distinto e independente da construção do syuzhet.

Porém, isso não significa dizer que o estilo tem maior importância que o syuzhet, mas "a estrutura estilística pode se tornar tão cuidadosamente organizada quanto a estrutura narrativa" (BORDWELL, 1985, p. 279, tradução nossa ${ }^{19}$ ). Como Thompson (1988) explica, a norma paramétrica é governada "por um princípio estruturante no qual a motivação artística se torna sistemática e em primeiro plano em todo o filme: a motivação artística cria padrões que são tão ou mais importantes que as estruturas do syuzhet" (p. 247, tradução nossa20).

Reforçamos que a narração paramétrica não é um movimento artístico em si, e pode ser encontrada em obras de diversos cineastas isolados e filmes esparsos. Bordwell aponta que "cineastas em períodos e culturas muito diferentes utilizaram princípios paramétricos. Alguns têm feito isso de forma consistente (Ozu, Bresson), outros esporadicamente (Lang, Dreyer, Fassbinder, Godard)" (BORDWELL, 1985, p. 310, tradução nossa ${ }^{21}$ ). Além disso, a escolha por uma análise de forma paramétrica é importante neste caso, porque, assim como Bordwell (1985) argumenta que acontece, por exemplo, com os filmes do cineasta Robert Bresson ${ }^{22}$, ela ajuda a revelar as causas formais de uma aura de mistério e transcendência que espectadores e críticos geralmente atribuem ao trabalho de David Lynch.

\section{Os parâmetros do Dale Cooper letárgico}

Twin Peaks: The Return trata de um comeback do mesmo universo da série produzida em 1990, contém os mesmos personagens, cenários e dá continuação às tramas da antiga série. Entretanto, em se tratando de aspectos narrativos,

No original: "stylistic structure can become as thoroughly organized as narrative structure".

No original: "structuring principle in which artistic motivation becomes systematic and foregrounded across a whole film: artistic motivation then creates patterns that are as important as or more important than the syuzhet structures".

No original: "filmmakers in widely differing periods and cultures have utilized parametric principles. Some have done so consistently (Ozu, Bresson), others sporadically (Lang, Dreyer, Fassbinder, Godard)". 
estilísticos e temáticos, a nova temporada apresenta pouca ou quase nenhuma semelhança com a original. Ainda assim, para fazer a análise do evento narrativo do retorno, precisaremos retomar alguns aspectos da série inicial. O personagem principal, Dale Cooper, ficou afamado como um personagem de televisão icônico por causa de suas principais características identitárias, como estar sempre com o visual alinhado e um terno preto impecável, fazer o sinal de positivo com os dedos (Figura 1), tomar café preto a todo momento (Figura 2) - e ainda dizer sua frase bordão logo após tomar o primeiro gole: "it's a damn good coffee" e comer a torta de cereja do restaurante Double R Diner (Figura 3). Outro motivo importante da série dos anos 1990 é o uso de sapatos de salto alto vermelhos por Audrey Horne (Sherilyn Fenn), que se apaixona por Cooper (Figura 4)23.

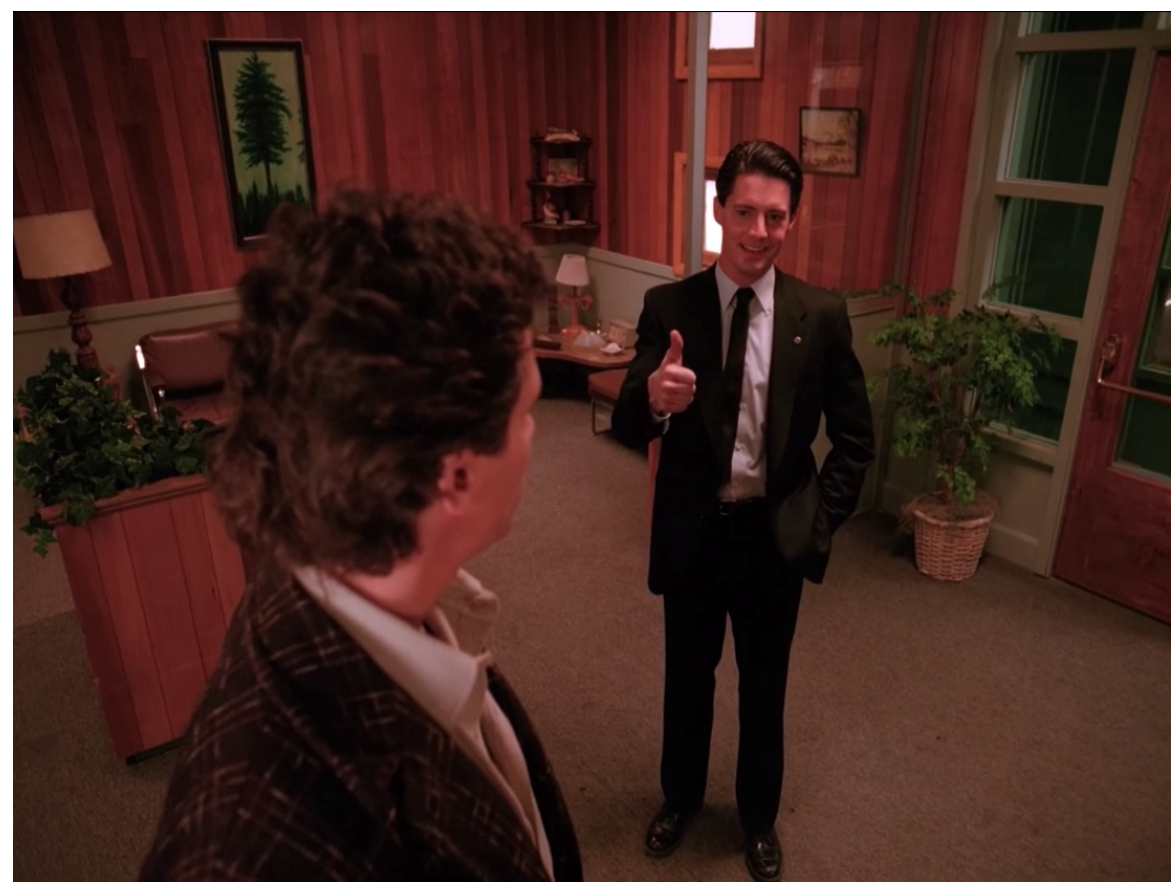

Figura 1: Motivo da série de 1990.

Fonte: frame da série televisiva Twin Peaks. 


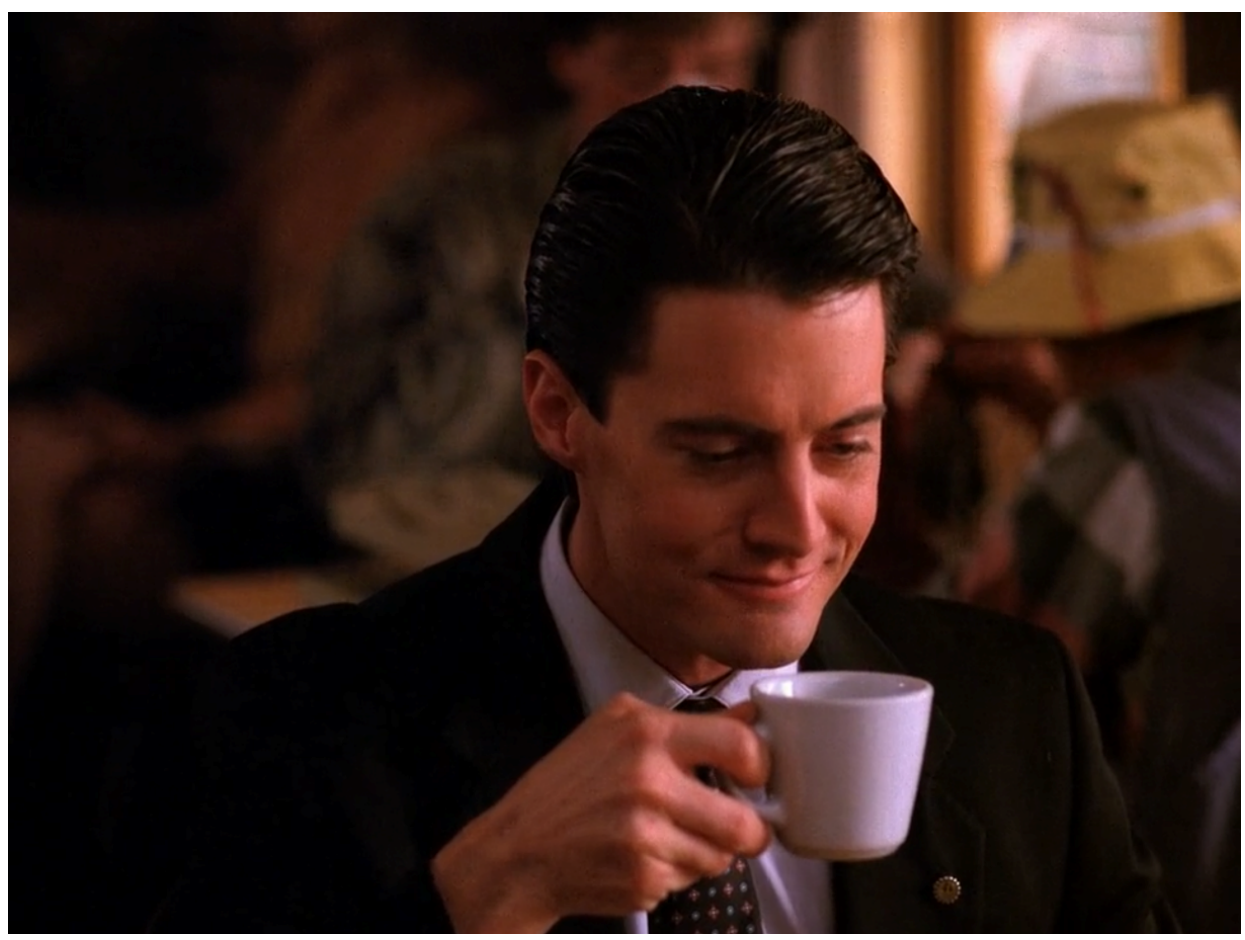

Figura 2: Motivo da série de 1990.

Fonte: frame da série televisiva Twin Peaks.

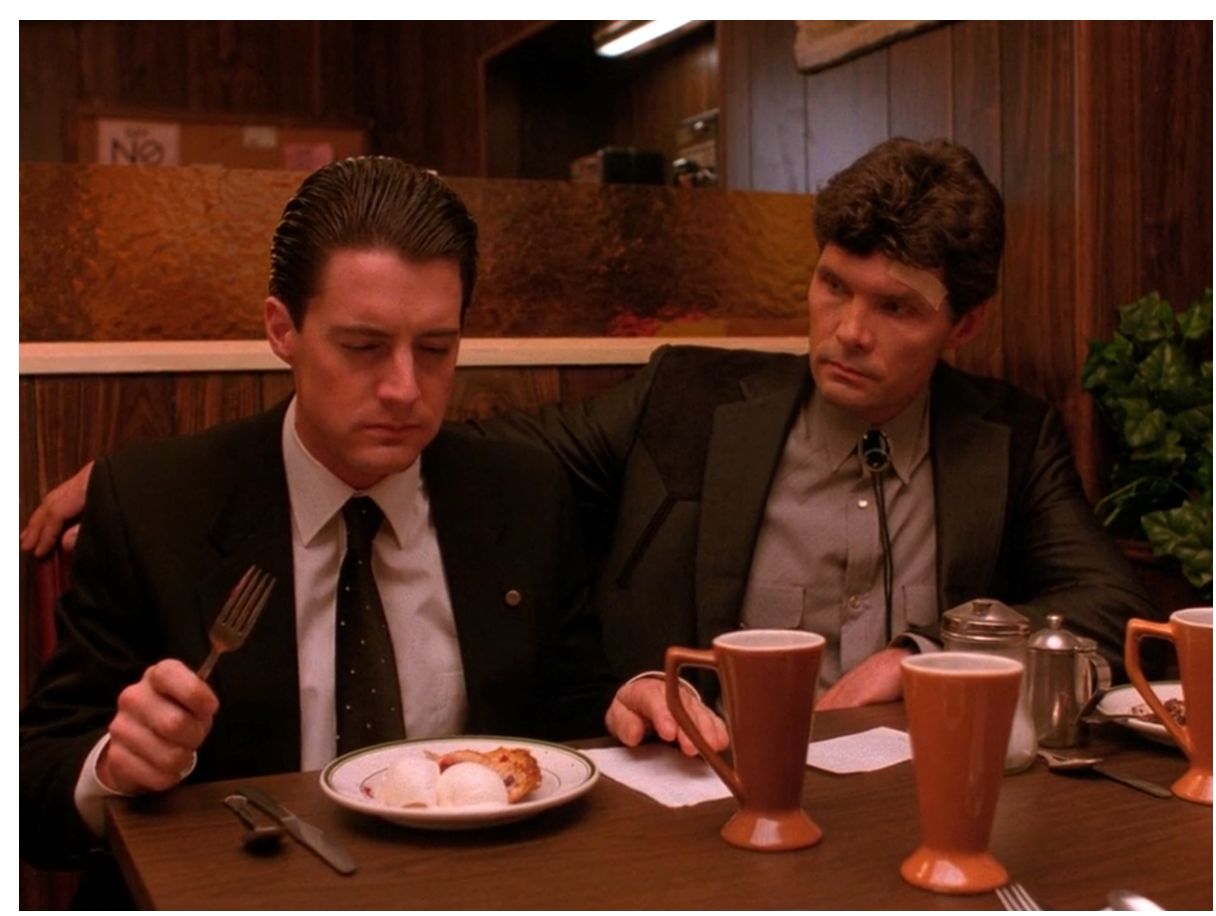

Figura 3: Motivo da série de 1990.

Fonte: frame da série televisiva Twin Peaks. 


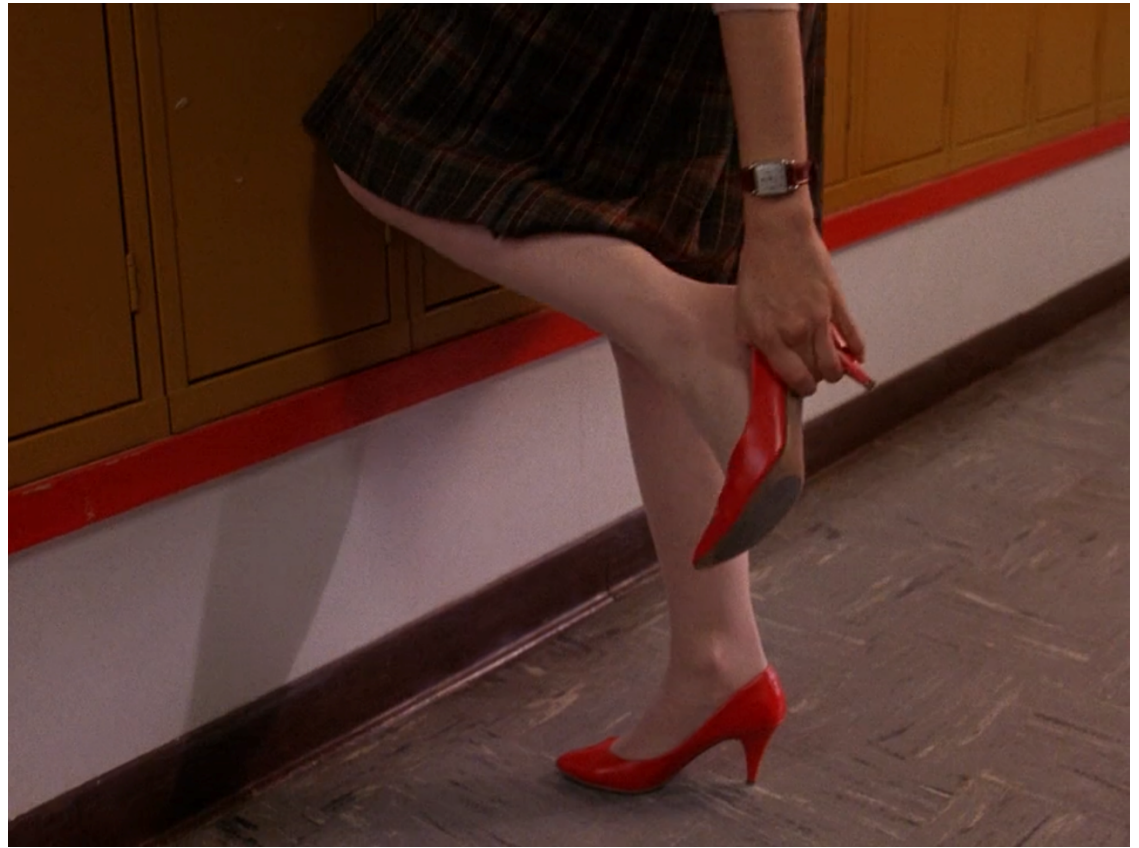

Figura 4: Motivo da série de 1990.

Fonte: frame da série televisiva Twin Peaks.

O evento narrativo "Dale Cooper letárgico" na série de 2017 é, ao mesmo tempo, uma linha narrativa com motivações muito simples - fazer o agente do FBI acordar deste estado mental para, enfim, confrontar seu doppelgänger do mal - e muito complexa em sua construção do syuzhet e estilo. Além de contar com o conhecimento prévio da série antiga por parte do espectador para ser entendido em sua totalidade, em mais de 2 horas de tela, acontecem pouquíssimos eventos na narrativa deste evento narrativo. Este entendimento perpassa um mecanismo presente nos filmes paramétricos que Bordwell (1985) denominou "norma intrínseca". O autor explica a função da norma intrínseca na análise do filme $O$ batedor de carteiras, dirigido por Robert Bresson:

[...] a narração paramétrica estabelece uma norma intrínseca distinta, geralmente envolvendo uma gama excepcionalmente limitada de opções estilísticas. Ela desenvolve essa norma de maneira aditiva. $O$ estilo, portanto, entra em relações de troca, dominantes ou subordinadas, com o syuzhet. [...] A estratégia de tratar o padrão estilístico como um conjunto de diferenças rigoroso, ainda que aditivo, colocado sobre a syuzhet não desafia os nossos processos normais de percepção de uma narrativa fílmica. A estratégia 
frustra, particularmente, o método principal de gerenciamento de tempo de assistir o filme - a construção de uma fabula linear. O filme paramétrico luta contra o tempo, levando ao extremo a tendência de 'espacialização'. (BORDWELL, 1985, p. 288-289, tradução nossa ${ }^{24}$ )

O que o autor expõe é que a estratégia de tratar o padrão estilístico como um conjunto rigoroso, ainda que aditivo, de diferenças estabelecidas sobre o syuzhet desafia nossos processos padrões de percepção da narrativa de um filme. Da mesma maneira, a norma intrínseca do evento narrativo "Dale Cooper letárgico", em The Return, se utiliza de uma gama limitada de opções estilísticas que varia do começo ao fim, independentemente do syuzhet. Essa norma é limitada a uma amplitude menor de variações possíveis sobre uma relação de imagens ou um parâmetro, mais espalhadas ao longo do filme. Um conjunto de componentes paramétricos passa por várias permutações, repetidas nos segmentos episódicos de estilo cuja norma se repete, com pequenas variações, e não fazem a narrativa avançar em direção a sua resolução - o despertar de Cooper. "Como de costume, as porções iniciais do filme estabelecem a norma intrínseca" (BORDWELL, 1985, p. 304, tradução nossa ${ }^{25}$ ) e, neste caso, o estilo do evento narrativo limita-se ao plano médio, com pouca mobilidade da câmera e enquadramentos centrais de certos "motivos" (THOMPSON, 198826). O clássico campo/contracampo é usado para exibir Cooper e os motivos, mas aqui isto não é usado como uma técnica convencional devido à velocidade do corte.

A norma intrínseca somada à repetição dos motivos tem função de quebra de expectativa causal dos acontecimentos da narrativa. Iniciemos exemplificando o momento, no quarto episódio de The Return, em que o vagaroso Cooper está na casa de Dougie Jones e, inesperadamente, sente vontade de urinar. Após algumas cenas of stylistic options. It develops this norm in additive fashion. Style thus enters into shifting relations, dominant or subordinate, with the syuzhet. The spectator is cued to construct a prominent stylistic norm, recognizing style as motivated neither realistically nor compositionally nor transtextually. The viewer must also form assumptions and hypotheses about the stylistic development of the film". 
cômicas, Cooper vê seu reflexo no espelho atentamente em um enquadramento muito semelhante ao utilizado na cena final da série nos anos 1990, e a estilização mantém o plano estático por um longo tempo na esperança de que o personagem possa se reconhecer e, talvez, acordar do transe; no entanto, ele continua no estado letárgico. Logo em seguida, o filho de Dougie, Sonny Jim, avista quem ele acha que seria o pai se trocando para o trabalho. Em um plano médio sem movimentação de câmera, Sonny Jim faz o sinal afirmativo com a mão e, em contracampo, Cooper replica, sorrindo (Figura 5); eis aí a aparição do primeiro motivo.

Logo após esta cena, Cooper, com a gravata na cabeça por ainda não entender como deve se vestir, desce para tomar o café da manhã. Após uma arrastada interação entre Cooper e a criança, a esposa de Dougie coloca uma xícara de café em cima da mesa e, quase que hipnotizado, Cooper olha fixamente para o seu conteúdo e pronuncia "coffee!" (Figura 6), como se estivesse recordando a antiga paixão. Ele dá um gole e, rapidamente, cospe o café no chão por estar muito quente, mantendo, sem embargo, um sorriso de contentamento por ter experimentado a bebida. A cena é cortada e Cooper continua no estado letárgico.

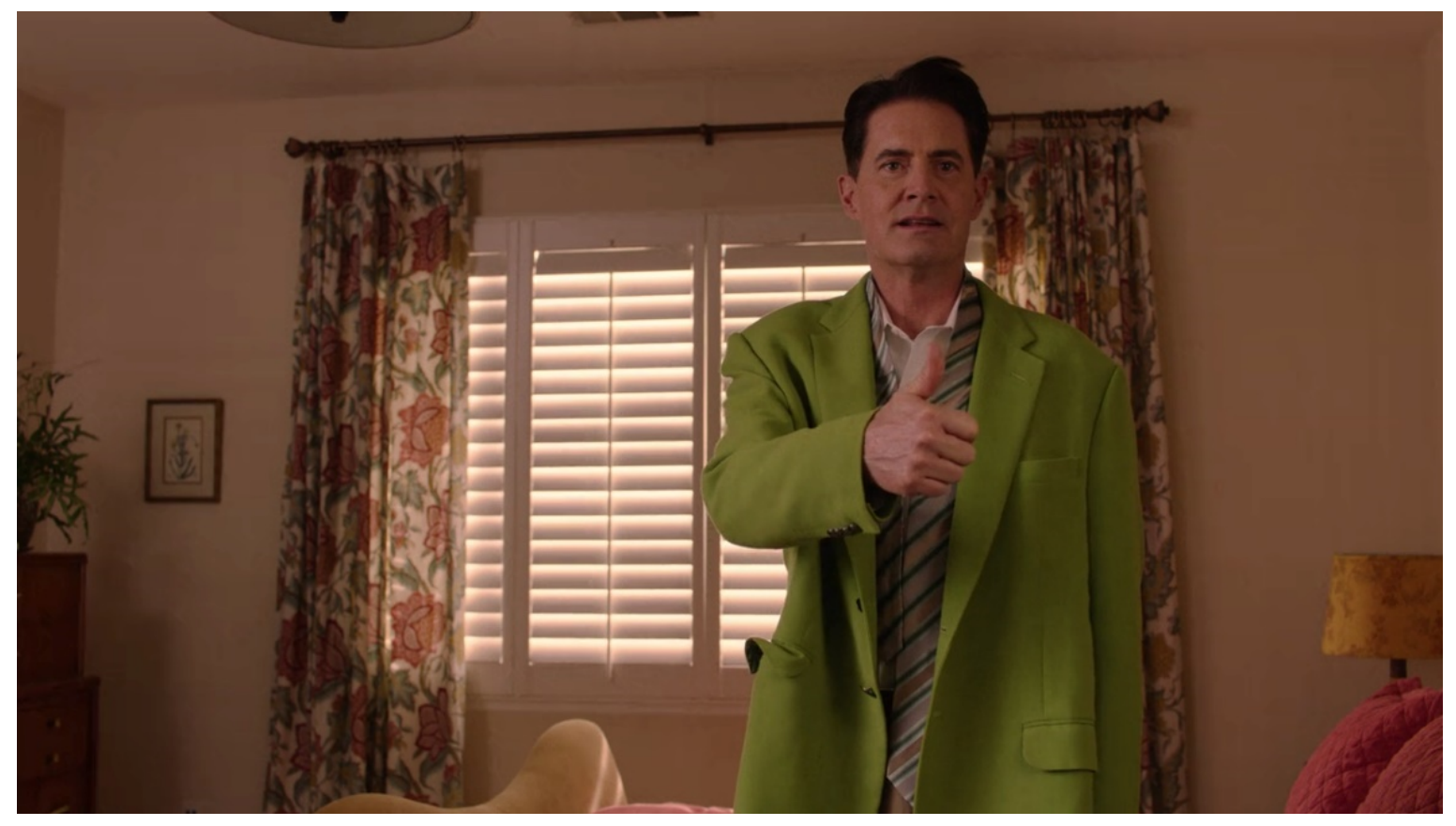

Figura 5: Motivo da série antiga que é reinterpretado em The Return Fonte: frame da série televisiva Twin Peaks: The Return 


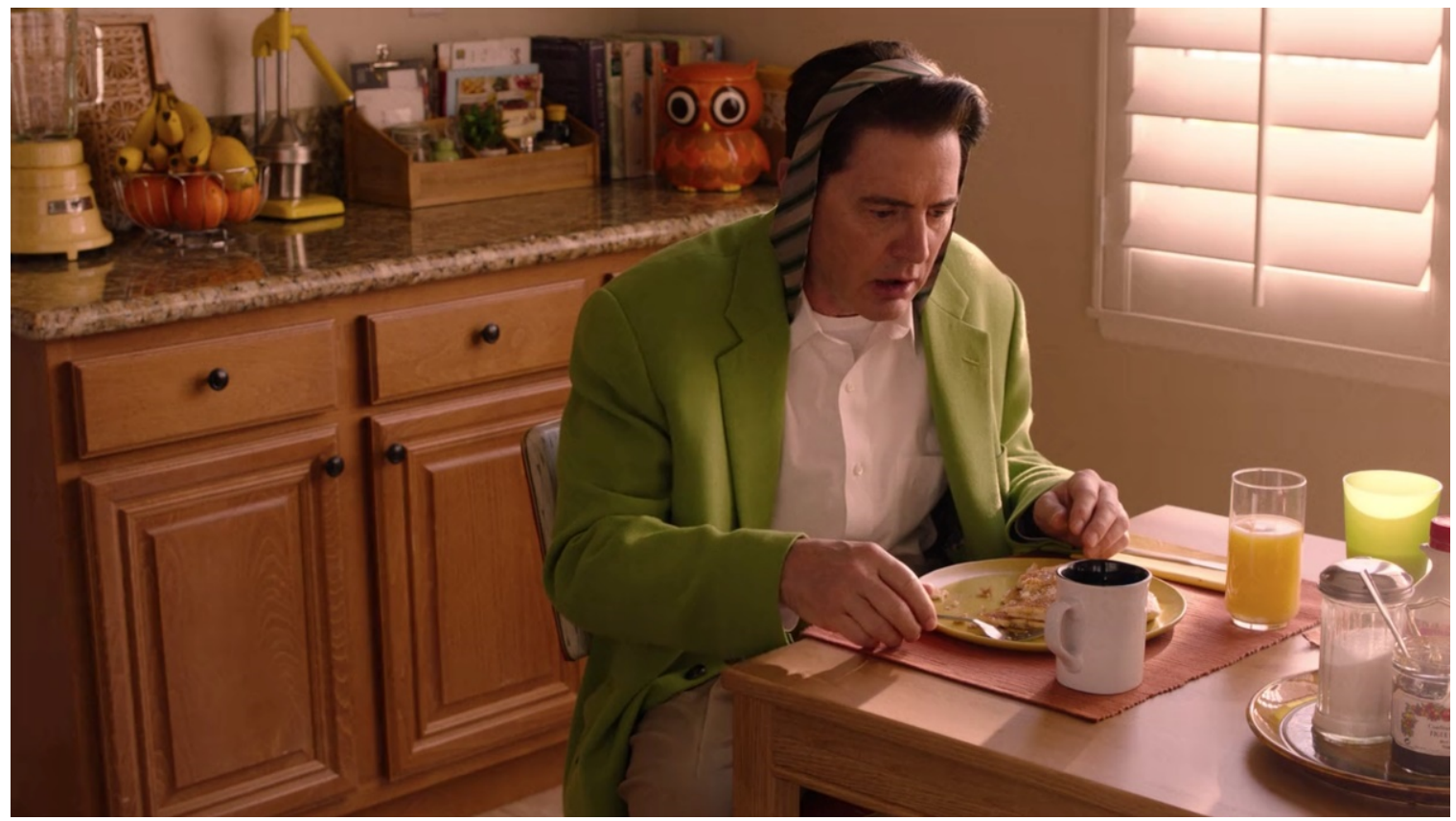

Figura 6: Motivo da série antiga que é reinterpretado em The Return Fonte: frame da série televisiva Twin Peaks: The Return

A partir das ocorrências de Cooper no episódio 4, podemos perceber que o evento narrativo se desenvolve em um contraste entre elementos banais e engraçados, e isso se repetirá, com pequenas variações, até que o agente do FBI desperte para seu estado normal. Além disso, podemos constatar a introdução dos motivos visuais que irão se repetir e variar ao longo de todo o evento narrativo. Lynch e Frost recuperam objetos e gestos que, no passado, se tornaram as características marcantes de Cooper, como o café preto ou o sinal positivo com a mão, e os transformam em motivos que são parte integral do estilo do evento narrativo.

Estes motivos não são desassociados à narrativa, pois são elementos já trabalhados na série original, mas, por outro lado, nunca servem para a construção da syuzhet, pelo contrário: retardam a elaboração de causa e consequência que a syuzhet clássica propõe. Cooper nunca desperta ao entrar em contato com os motivos que visivelmente remeteriam a sua antiga caracterização e, assim, a narrativa não avança em direção à resolução. A maioria desses motivos opera de modo tão inegável e perceptível que não demanda uma extensiva análise, porém devemos pensar sobre 
como se dão as apresentações dos motivos durante todo o evento narrativo para pontuar e ratificar as demais características paramétricas.

O episódio 5 nos apresenta um novo motivo. Janey-E leva Cooper para o trabalho de Jones, e o personagem repara em uma estátua de um policial logo na frente do edifício. Novamente, uma cena lenta e estática de campo/contracampo, enquadrando primeiro Cooper para, logo em seguida, enquadrar a estátua, que empunha um revólver em posição de disparo. Cooper replica o movimento da estátua, assim como fez com Sonny Jim, como se estivesse lembrando de sua história pregressa como agente federal do FBI (Figura 7) e, novamente, o estilo visual faz questão de alongar os planos para evidenciar o objeto que tanto foi caro ao personagem na série de 1990. Adiante, Cooper lentamente vai até a entrada do prédio, onde encontra um colega de trabalho de Dougie segurando vários copos de café. Imediatamente Cooper prende-se às bebidas, remetendo, como no café da manhã do episódio 4, a sua antiga característica identitária. Justamente devido ao café, Cooper segue Phil até o elevador e chega ao trabalho, mas não sem antes dar um bom gole, que o faz arregalar os olhos.

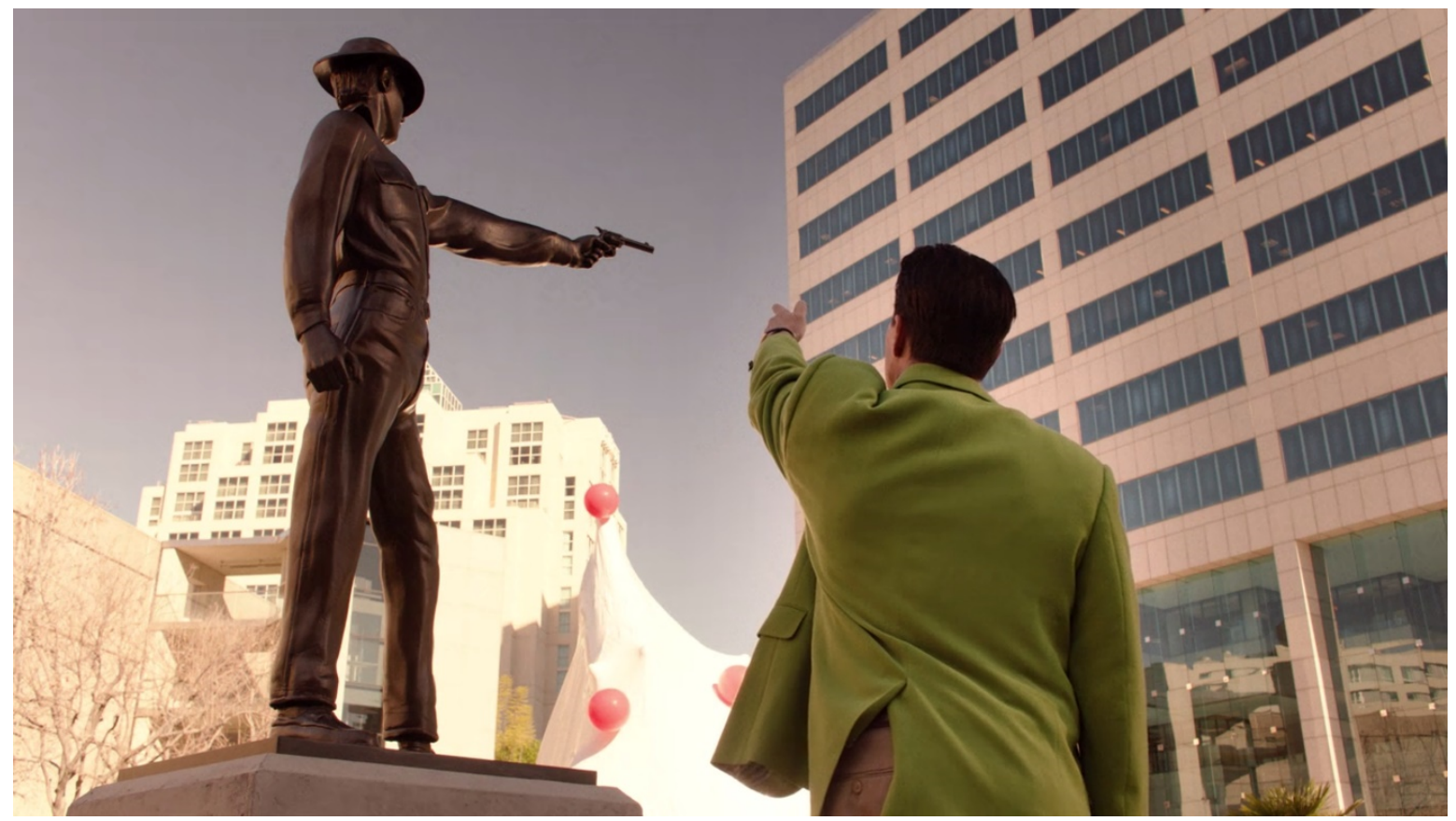

Figura 7: Motivo da série antiga que é reinterpretado em The Return Fonte: frame da série televisiva Twin Peaks: The Return. 
Temos em outro episódio um escalonamento na construção de expectativa, através da elaboração estilística de que Cooper irá despertar baseado nos elementos marcantes da própria narrativa de 1990, porém, de novo, a esperança é anulada e seguimos com o personagem em estado letárgico. $O$ motivo do café manifesta-se também no episódio 6 e é muito próximo, estilisticamente, de como ele foi exibido no episódio 5, produzindo praticamente uma cacofonia visual ${ }^{27}$.

Já no episódio 7, podemos ver Cooper em ação pela primeira vez em quase sete horas televisivas da série, todavia a cena, em sua totalidade, dura poucos segundos. Neste episódio, um assassino de aluguel corre na direção de Cooper e Janey-E e aponta uma arma de fogo na direção de quem ele pensava ser Jones. Cooper, em uma cena com movimentação de câmera dinâmica e repleta de cortes, bloqueia a arma do assassino e, em seguida, o atinge com um golpe no pescoço, desarmando-o. Em uma cena que remete, de imediato, aos melhores momentos do agente federal na série de 1990, Lynch e Frost desafiam a nossa percepção do evento narrativo, pois transformam completamente não só a estilização visual que vínhamos acompanhando até então, mas também a agilidade com que vemos o personagem agir. Depois de somente 25 segundos de ação, Cooper retorna ao estado letárgico como se nada tivesse acontecido e Lynch e Frost, mais uma vez, manipulam a construção da expectativa com um constructo de personagem da série anterior. Vale ressaltar que esta é uma das únicas variações estilísticas durante todo o evento narrativo analisado.

No episódio 9, Cooper e Janey-E estão sentados na sala de espera da delegacia para esclarecer o ocorrido com o assassino e um policial se aproxima de Cooper, e entrega a ele uma xícara de café, repetindo, assim, o motivo de outros episódios. O policial se retira de cena e novamente um padrão estilístico se repete. Cooper é enquadrado em primeiro plano e depois de um vagaroso travelling in em seu rosto, vemos outro motivo surgir no contracampo: 
a bandeira dos Estados Unidos e, no fundo, a canção America the Beautiful, performada pela banda da Força Aérea Americana (Figura 8).

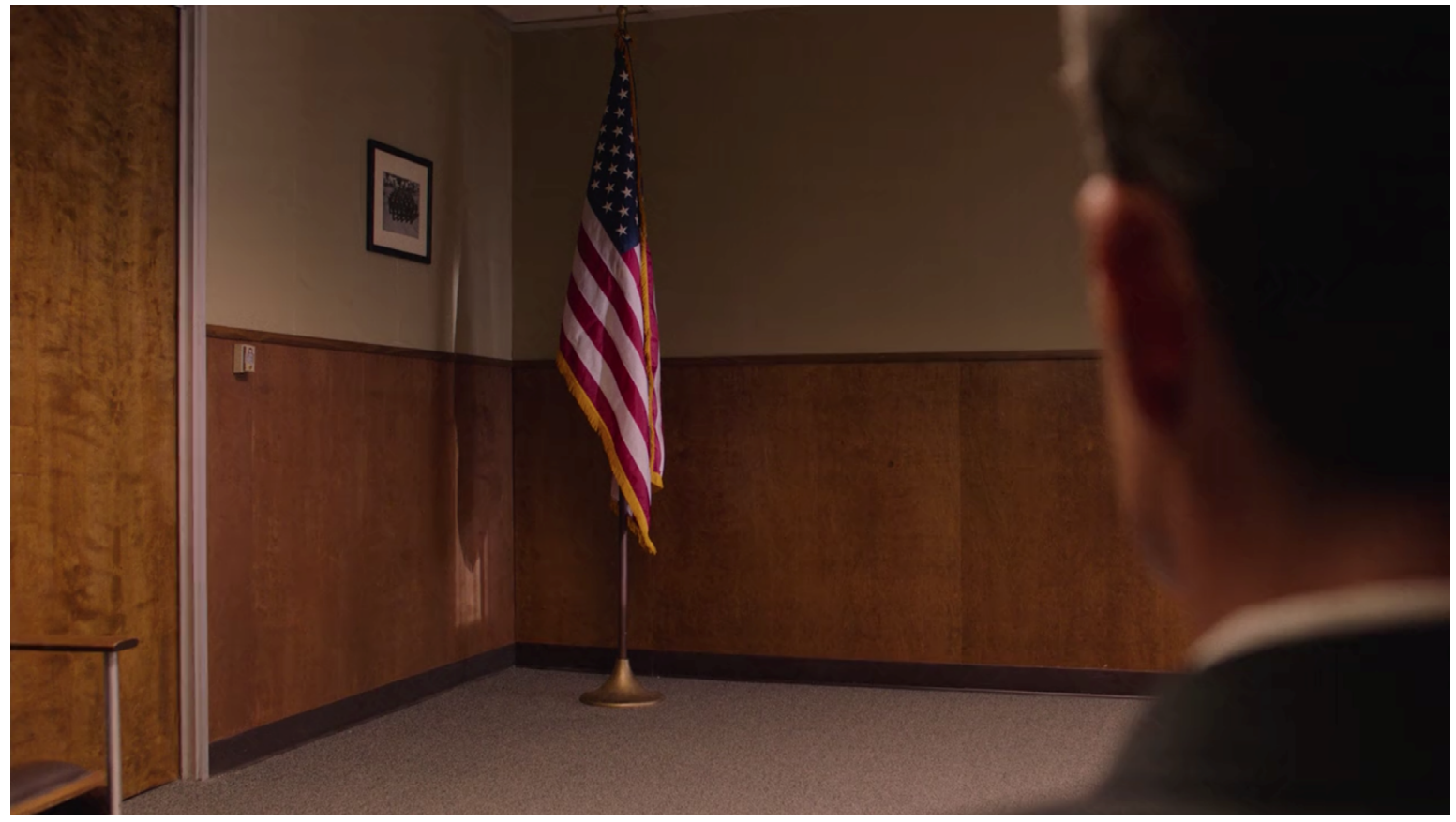

Figura 8: Motivo da série antiga que é reinterpretado em The Return Fonte: frame da série televisiva Twin Peaks: The Return.

Um outro campo/contracampo se repete e, em seguida, entra uma mulher de salto alto vermelho pela porta que estava à esquerda da bandeira enquadrada, com um movimento de câmera lateral enquanto ela anda até a direita do quadro (Figura 9). Ela continua caminhando, mas a câmera voltase para uma tomada que tinha ficado para trás. Aqui, vemos o motivo da nação americana, pela qual Cooper desempenha toda a sua afeição e seu esforço de trabalho, simbolizada pela bandeira e reforçada pela canção de fundo. Observamos também o motivo do salto alto vermelho, característica marcante do visual do interesse romântico de Cooper na série de 1990, porém nem seu patriotismo nem sua paixão amorosa o despertam de seu estado letárgico. Posteriormente, a câmera focaliza a tomada, que não tem ligação nenhuma com a série anterior, mas são utilizados os mesmos recursos estilísticos (campo e contracampo lentíssimos) já aplicados nos padrões anteriores. 


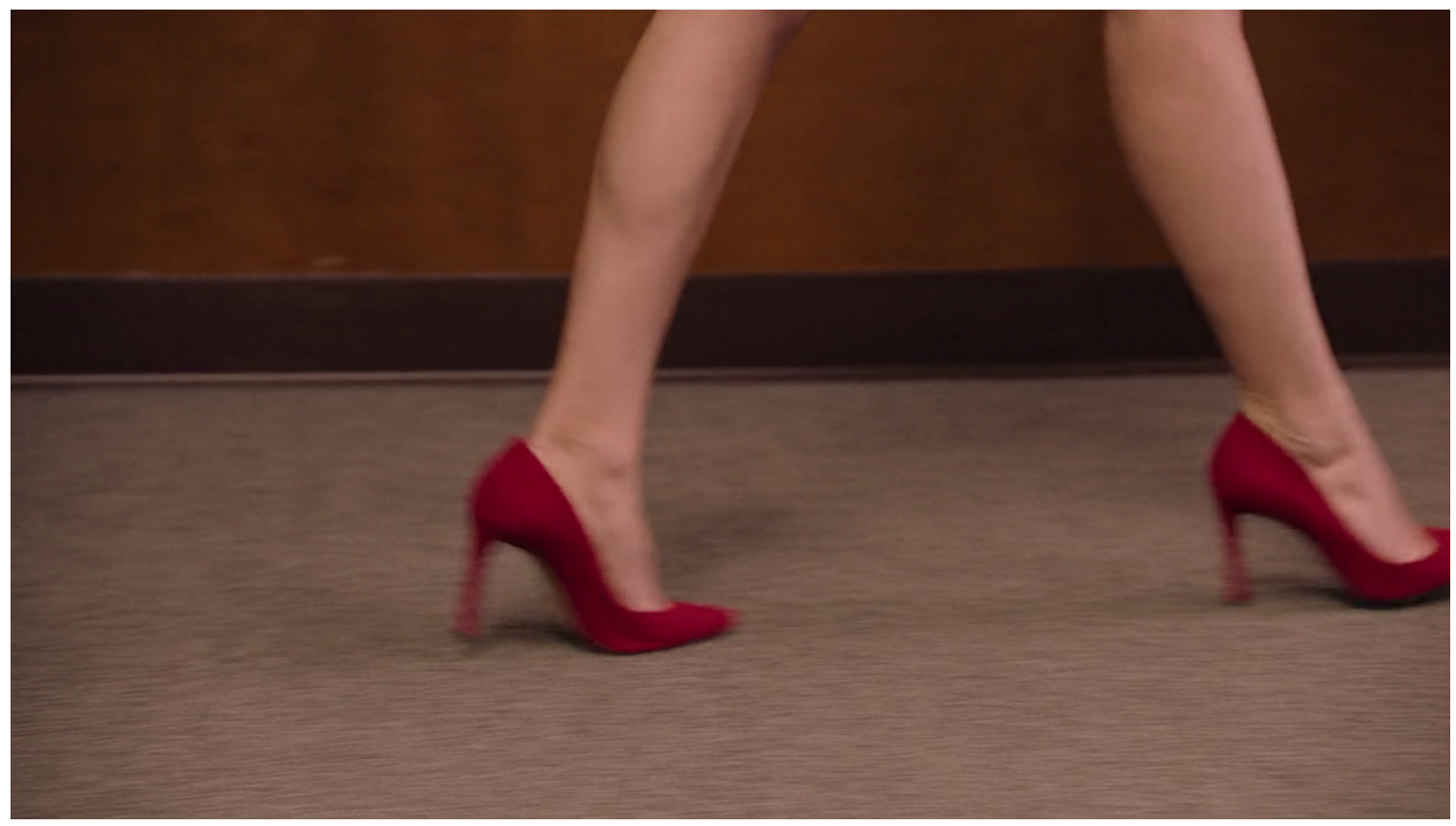

Figura 9: Motivo da série antiga que é reinterpretado em The Return Fonte: frame da série televisiva Twin Peaks: The Return.

No episódio 11, Cooper, enquanto toma café, conversa com o chefe de Jones para participar de uma negociação. Quando o agente desce do prédio, Mike, um dos seres da outra dimensão, o chama para entrar em um café, de onde Cooper sai com uma grande caixa de papelão direto para a negociação. No local combinado, os negociantes questionam "Dougie" a respeito do conteúdo da caixa, porém ele se mantém incapaz de responder devido a sua letargia. Desconfiados, um deles se aproxima da caixa e a abre: uma torta de cereja. A transação é um sucesso e os envolvidos vão comemorar comendo a torta presenteada por Cooper em um restaurante. Cooper, com mordidas vagarosas, se delicia com um pedaço (Figura 10). Nota-se que sua expressão facial é análoga a que vimos na série original quando ele experimenta a torta (Figura 3), o que aproxima visualmente o personagem àquele momento. 


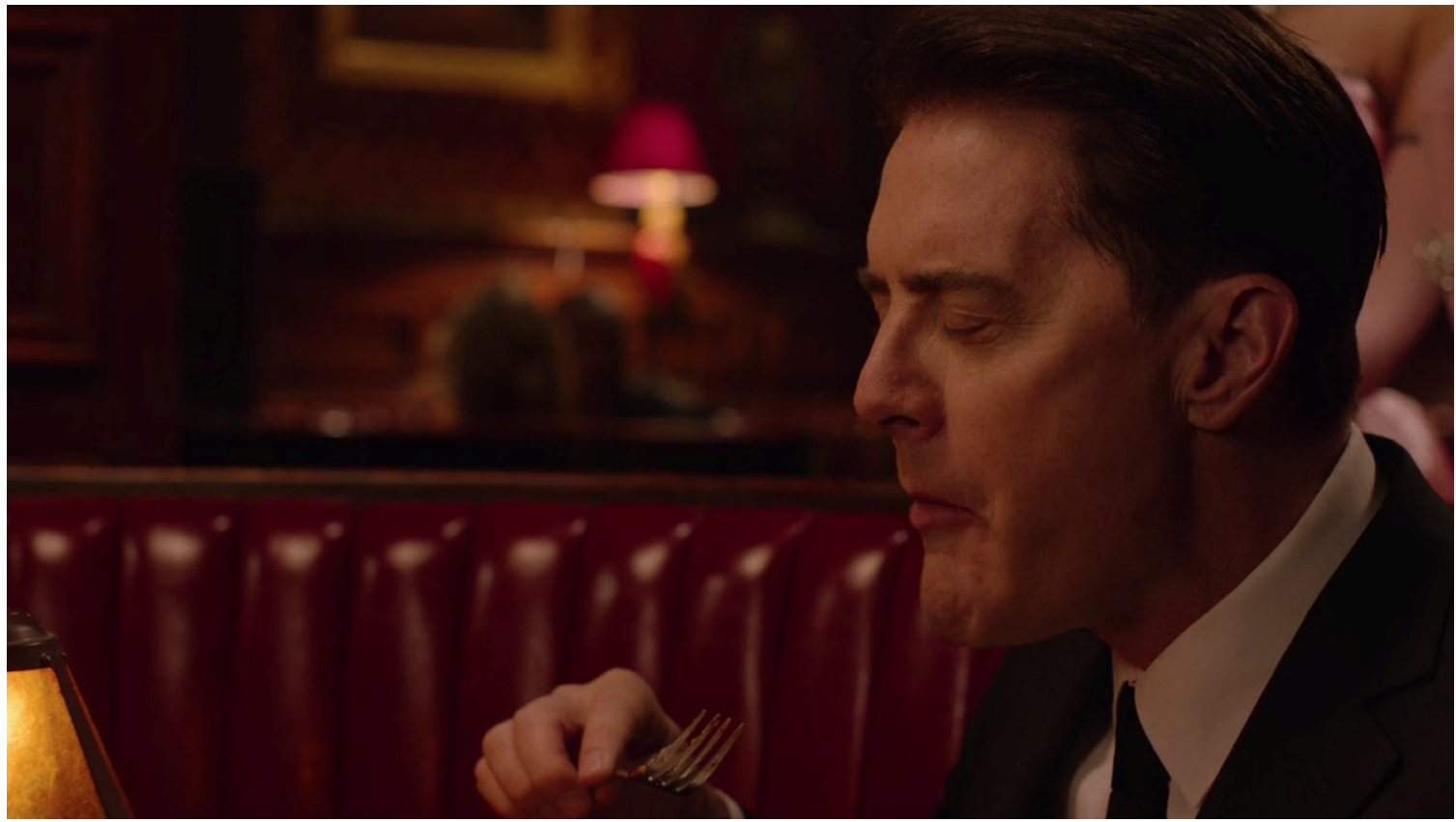

Figura 10: Motivo da série antiga que é reinterpretado em The Return

Fonte: frame da série televisiva Twin Peaks: The Return.

Um dos negociadores come um pedaço e murmura "This pie is so damn good", frase bordão de Cooper na série original e que ainda não havia sido pronunciada em nenhum momento em The Return. De imediato, Cooper para de comer e atenta-se ao que foi dito, repetindo "damn good", e abre os olhos em espanto, como se seus estímulos estivessem se reavivando. Esta falsa percepção é rapidamente quebrada quando o negociador pede um brinde levantando seu copo e Cooper, ainda letárgico, ergue as mãos para pegar a bebida. Assim, o espectador é introduzido a um dos motivos mais emblemáticos da série dos anos 1990: o bordão de Cooper. A instantânea associação com o personagem do antigo agente federal é inevitável. Entretanto, esta esperada ligação de causa e consequência é negada, mais uma vez, pelo syuzhet.

Agora que todos os possíveis motivos que poderiam despertar Cooper do seu transe foram apresentados, suas repetições, com pequenas variações, no episódio 13 (o café e a torta de cereja), já se tornam previsíveis: o espectador entende que estes motivos não o despertarão. Depois de seis episódios analisados neste evento narrativo, podemos denotar que estes motivos se tornam parte de 
uma norma intrínseca do trabalho paramétrico, que existem somente para chamar atenção para eles mesmos e que a relação espacial de Dale Cooper com os motivos funcionará como material para variantes de estilo durante todo o evento narrativo. No episódio 15, Janey-E oferece um bolo para Cooper: a seguir, acompanhamos, por 1 minuto e 20 segundos, o personagem dando lentas garfadas no bolo, em um plano de enquadramento totalmente imóvel, até que ele liga a televisão e está passando o filme Crepúsculo dos deuses (Sunset Boulevard, 1950).

De repente, outra referência à série original: um personagem do filme diz "chame Gordon Cole", que coincidentemente é o mesmo nome do antigo chefe de Cooper no FBI, interpretado pelo próprio David Lynch ${ }^{28}$. Em um travelling in no rosto de Cooper, vemos a mesma expressão facial de espanto de quando ele ouviu "damn good" no episódio 11 . O motivo da tomada - que até então era o único que não remetia ao seriado anterior - reaparece com sons de curtos elétricos ao fundo - aí sim remetendo ao universo anterior de Twin Peaks, que já trazia tais efeitos sonoros como um motivo. Cooper levanta-se, engatinha até a tomada, introduz nela o garfo com que comia o bolo e leva um imenso choque elétrico. Cooper desperta de sua letargia no episódio seguinte e volta a ser o agente especial do FBI, que havia desaparecido há 25 anos.

\section{Narração paramétrica na ficção televisiva}

Bordwell (1985) expõe que "padrões estilísticos tendem a ser veículos para o processo do syuzhet de nos levar a construir a fabula" (p. 275, tradução nossa ${ }^{29}$ ), como no caso da narração clássica, no qual a técnica cinematográfica é usada, principalmente, para reforçar o arranjo causal, temporal e espacial dos eventos no syuzhet e o estilo, neste caso, seria "invisível". Ainda segundo o autor, na narração do "cinema de arte", por mais que o estilo seja mais proeminente em virtude de seu desvio das normas clássicas, também "permanece subordinado 
às funções definidas pelo syuzhet: criar realismo, expressar subjetividade, comentário autoral ou uma combinação desses fatores" (p. 275, tradução nossa ${ }^{30}$ ). No entanto, no evento narrativo de Twin Peaks: The Return analisado, o estilo é organizado de maneira distinta da construção do syuzhet. Por outro lado, porém, os artifícios estilísticos alcançam uma proeminência estrutural que é mais do que simplesmente ornamental.

Ainda segundo Bordwell (1985), o cinema de arte solicita uma leitura simbólica para interpretar o filme e é exatamente burlando esta regra que Lynch e Frost operam na construção desta narrativa, pois aqui não há o que interpretar. O evento narrativo também não enfatiza uma ambiguidade psicológica e não expressa a subjetividade do personagem como na narração do cinema de arte, mas valoriza a opacidade justamente porque Cooper está em um estado em que não há profundidade psicológica. Por outro lado, também, o evento narrativo não contém a redundância de uma narrativa clássica: o método de Lynch e Frost para evitar que a história caminhe para a resolução (Cooper voltar a agir como um agente do FBI) não é por causa e consequência.

Não é ignorado que, enquanto Cooper não desperta de seu transe, ele interage com Sonny Jim, Janey-E, o chefe do trabalho de Dougie, entre outros personagens, mas essas ações não caminham em direção a solucionar o problema do personagem principal. Levando em consideração a jornada de Cooper para despertar, o evento narrativo é um grande tempo morto, não existindo desenvolvimento linear causal. Enquanto a syuzhet apresenta os motivos analisados que supostamente levariam à evolução da história do personagem, o estilo apresenta-se em longos planos mortos, muitas vezes estáticos, que se alongam para o corte. Cooper tem o objetivo de despertar com a justificativa de acabar com as maldades que seu doppelgänger do mal vem praticando em uma linha narrativa paralela à sua, mas parece que cada vez mais ele se distancia de seu propósito, ou seja, assistimos a quase duas 
horas de uma anti-ação. Por mais que este seja um acontecimento narrativo, suas repetições e simetrias estilísticas não servem à ação da syuzhet e não ajudam a reconstruir a linha da fabula. Em vez disso, muito do interesse estilístico permanece independente das funções narrativas.

Não perdemos de vista, na análise, que as longas cenas de Cooper tomando café preto em diversos momentos da narrativa ou comendo torta de cereja no restaurante Double R Diner enquanto nenhuma outra ação ocorria já existiam em Twin Peaks nos anos 1990; porém, na série atual, diferentemente de antes, essas cenas têm o papel de gerar incômodo justamente porque remetem à série antiga, mas o personagem que vemos representado na tela não chega nem perto do entendimento que os espectadores carregavam de Dale Cooper. Carregado de ironia em relação à série anterior, o valor deste evento narrativo está menos na temática a que ele se propõe - mesmo porque nenhuma temática significante é vislumbrada no horizonte da narrativa - e mais na habilidade de mudar a percepção habitual do espectador das convenções audiovisuais por meio da desfamiliarização. Mais do que isso, o evento narrativo tem o mérito de transformar as convenções estabelecidas pela própria série Twin Peaks nos anos 1990.

Como vimos, na época de sua exibição, Twin Peaks foi uma das pioneiras nos contornos de um novo modo de narrativa televisiva que vinha surgindo na época. A série experimentou, de diversas formas, inovar a narrativa de seu tempo. Além disso, Twin Peaks abriu as portas para séries como Arquivo $X$, Lost e tantas outras ao longo dos anos. Todas estas mudanças estéticas e narrativas oportunizadas pela série fizeram que se abrissem portas para que as séries se tornassem um objeto de culto (CARLOS, 2006; ESQUENAZI, 2011; THOMPSON, 2003).

Por isso, Twin Peaks pode ser considerado um dos responsáveis pela introdução de uma seriefilia, que foi sendo desenvolvida ao longo dos anos. Para François Jost, a seriefilia pode ser entendida como uma prática cultural e "substituiu a cinefilia e, embora dela se distinga, ela se apropriou de alguns de seus traços: o conhecimento preciso das intrigas, das temporadas, dos comediantes, 
de suas carreiras, dos autores de suas trajetórias e dos acasos e percalços da realização de seus projetos, das datas de difusão etc." (JOST, 2012, p. 24). A esse respeito, Mungioli ainda acrescenta que:

A compreensão desse fenômeno comparando-o à cinefilia possui implicações importantes que, para além da paixão pelas tramas indica o crescimento de uma cultura de séries [...] e não apenas o conhecimento de uma série em especial (embora isso seja também possível). Também implica a criação e o desenvolvimento de grupos especializados para assistência e discussão das séries, incluindo reuniões e encontros presenciais ou online para debates e realização de publicações (online ou impressas) que extrapolam os limites da academia, da indústria de comunicação ou dos chamados profissionais da televisão. É, portanto, a dimensão cultural e simbólica desses produtos aliada à sua importância econômica na indústria de televisão e de entretenimento em geral que tem chamado a atenção de pesquisadores e criado terreno propício para a cultura das séries. (MUNGIOLI, 2017, p. 2)

Com certeza, Twin Peaks foi uma das séries pioneiras nesse processo cultural. Ferraraz (2007) aponta que o fato de o mundo misterioso de Twin Peaks ter sido exibido pela televisão contribuiu para que o seriado tenha se tornado objeto de culto como nenhuma outra obra de David Lynch até então. Alguns dos exemplos desta seriefilia é que até hoje é editada uma revista sobre a série, chamada Wrapped in Plastic, ou o fato de serem feitas convenções anuais de fãs de Twin Peaks na cidade em que a obra foi filmada, em que atores, roteiristas e diretores da série são convidados para dar palestras ${ }^{31}$.

Seja no aspecto estético ou narrativo, seja no aspecto da cultura de fãs, Twin Peaks de fato possibilitou novos caminhos para se produzir e se consumir as séries televisivas que viriam a seguir, conforme apontam Thompson (2003) e Mittell (2012, 2015). Para Mittell (2012, p. 38), Twin Peaks "proporcionou aos espectadores e aos executivos da televisão um vislumbrar das práticas narrativas que as séries iriam desbancar", abrindo "as portas para outros programas que no início da década de 1990 tomaram a liberdade criativa na forma de 
narrar, mais notadamente Seinfield (1989-1998) e The X-Files (1993-2002). Ambos acrescentam aspectos essenciais ao repertório da complexidade narrativa com maior sucesso de audiência".

Muitas destas mudanças radicais que foram introduzidas na narrativa televisiva daquela época e que contribuíram para esta criação de um "culto seriefílico" já foram absorvidas pela maioria das séries televisivas atuais, transformando (e talvez padronizando) completamente estas narrativas. O que era desafiador e complexo para a época de Twin Peaks pode não gerar hoje o mesmo efeito nos espectadores. Como podemos ver na análise do evento narrativo "Dale Cooper letárgico", usando uma narrativa paramétrica carregada de repetições de motivos e com poucas variações, Lynch e Frost em The Return subvertem grande parte das convenções que a própria série original ajudou a criar.

Cada cena analisada provoca o espectador com a possibilidade de relações causais e temporais com cenas da antiga série, mas parece não levar a lugar nenhum. Através do modo paramétrico, a fabula nos nega de novo e de novo dar prosseguimento à história, com a estrutura processando sua lógica própria. Se o espectador tentar presumir que o café preto é mais do que um café preto ou uma torta de cereja é mais do que uma torta de cereja, ou seja, se o espectador tentar interpretar simbolicamente estas variações de motivos em relação à ação da syuzhet ou em relação à série antiga, provavelmente acabará frustrado.

Em vista disso, a hipótese desse artigo é de que, em Twin Peaks: The Return, David Lynch e Mark Frost se propuseram a romper com muitas das convenções que eles ajudaram a construir nos anos 1990. Esta proposta é acentuada pela utilização do modo paramétrico, pois ele "explora os próprios limites da capacidade do espectador. O senso de uma ordem cujo grão mais fino podemos avistar, mas não compreender, ajuda a produzir efeitos conotativos [...] que surgem de uma manipulação formal que, em um sentido forte, 
não significa nada" (BORDWELL, 1985, p. 306, tradução nossa ${ }^{32}$ ). Talvez o que Lynch e Frost buscaram afirmar, em relação a série antiga, fosse: uma torta de cereja é só uma torta de cereja. E, assim, engendraram uma série que, uma vez mais, conseguiu trazer novas experimentações à ficção televisiva, especialmente no que tange aos aspectos estilísticos e narrativos.

\section{Referências}

ARAÚJO, I. Volta de 'Twin Peaks' é a grande aventura cinematográfica do ano. Folha de S.Paulo, São Paulo, 31 jul. 2017. Disponível em: https://tinyurl.com/ a2mb5afy. Acesso em: 10 fev. 2020.

BORDWELL, D. Narration in the fiction film. Madison: University of Wisconsin Press, 1985.

BORDWELL, D. Sobre a história do estilo cinematográfico. Campinas: Unicamp, 2013.

CARLOS, C. S. Em tempo real: Lost, 24 horas, Sex and the City e o impacto das novas séries de TV. São Paulo: Alameda, 2006.

ESQUENAZI, J. As séries televisivas. Lisboa: Texto \& Grafia, 2011.

FERRARAZ, R. O mundo estranho de Twin Peaks: um pequeno marco nos seriados de televisão. RuMoRes, São Paulo, v. 1, n. 1, 2007. 
FERRARAZ, R; MAGNO, M. I. C. O retorno a um mundo estranho e maravilhoso: Twin Peaks: The Return e o inquietante freudiano - uma análise focada no estilo individual e em certas estratégias recorrentes de David Lynch. In: ROCHA, S. M.; FERRARAZ, R. (org.). Análise da ficção televisiva: metodologias e práticas. Florianópolis: Insular, 2019. p. 149-173.

FREUD, S. O inquietante. In: FREUD, S. Obras Completas. São Paulo: Companhia das Letras, 2010. p. 247-283. v. 14.

JOST, F. Do que as séries americanas são sintoma? Porto Alegre: Sulina, 2012.

MITTELL, J. Complex TV: the poetics of contemporary television storytelling. Nova York: New York University Press, 2015.

MITTELL, J. Complexidade narrativa na televisão americana contemporânea. MATRIZes, São Paulo, v. 5, n. 2, p. 29-52, 2012.

MUNGIOLI, M. C. P. Poética das séries de televisão: elementos para conceituação e análise. In: CONGRESSO BRASILEIRO DE CIÊNCIAS DA COMUNICAÇÃO, XL., Curitiba, 2017. Anais [...]. Curitiba: Intercom, 2017.

ROCHA, S. M.; PUCCI JR., R. L. Introdução. In: ROCHA, S. M.; PUCCI JR., R. L. (org.). Televisão: entre a metodologia analítica e o contexto cultural. São Paulo: A lápis, 2016. p. 9-18.

THOMPSON, K. Breaking the glass armor: neoformalist film analysis. Nova Jersey: Princeton University Press, 1988.

THOMPSON, K. Storytelling in film and television. Cambridge: Harvard University Press, 2003. 
TWIN Peaks: the return. Produção de David Lynch e Mark Frost. Los Angeles: Showtime, 2017. Online (1.080 min.).

XAVIER, I. O discurso cinematográfico: a opacidade e a transparência. São Paulo: Paz e Terra, 2005.

submetido em: 9 jun. 2021 | aprovado em: 18 out. 2021 